DOI: 10.26693/jmbs06.01.327

UDC 577.175.5/.6-055.1/.2

Popova L. D., Vasylyeva I. M., Nakonechna O. A.

\title{
CORRELATION DIFFERENCES BETWEEN SEX AND STRESS HORMONES IN MEN AND WOMEN
}

\author{
Kharkiv National Medical University, Ukraine
}

popova_Id@ukr.net

The excessive aggression is an actual problem of modern society but the mechanisms of aggressiveness development have not been sufficiently investigated. Women aggression is considered to differ from men one and results obtained on males cannot be extrapolated on females. Sex hormones have a crucial role in the generation of sexually dimorphic aggression circuits during development and their maintenance during adulthood. Hypothalamic pituitary adrenal axis and sympathoadrenal system are major neuroendocrine systems that respond to stress. Stress hormones are involved into behavioral reactions of organism. Gonadal, hypothalamic pituitary adrenal axes, and sympathoadrenal system are tightly interrelated and every of them can influence another one.

The purpose of the study was to estimate correlation differences between sex and stress hormones in men and women.

Material and methods. Forty healthy young people aged 18 to 22 years with a body mass index of 19-24 (21 women and 19 men) were enrolled in the study. Hormone levels in blood serum were determined by Testosterone, Estradiol, Cortisol ELISA kits (Italy), Epinephrine/Norepinephrine (EPI) ELISA kit (China).

Results and discussion. In all phases of the menstrual cycle, the level of cortisol in women was lower than in men, but in the luteal phase these differences were not statistically significant. In all phases of the menstrual cycle, the blood serum norepinephrine content in women was lower than in men, but in the follicular phase these differences were not statistically significant. The level of epinephrine in women during ovulation and luteal phase did not differ from the level of epinephrine in men, but in follicular phase it was significantly lower. Calculations of correlations between individual hormones revealed a significant difference between them in men and women. Positive correlations between testosterone and estradiol and between cortisol and epinephrine; a strong negative correlation between epinephrine and testosterone/ norepinephrine ratio were found in men. Positive correlation between testosterone and cortisol and negative correlation between estradiol and cortisol/testosterone ratio were revealed in women.

Conclusion. In women, strong correlations were found between cortisol and sex hormones; in men, strong interrelationship was revealed between cortisol and epinephrine. Both in men and in women (in all phases of the menstrual cycle), high positive correlations between testosterone/norepinephrine and cortisol/norepinephrine ratios were observed.

Keywords: testosterone, estradiol, cortisol, epinephrine, norepinephrine, men, women.

Research relation to the programs, plans, and department themes. The study was carried in accordance with the research plan of Kharkiv National Medical University "Biochemical mechanisms of dysmetabolic processes development under the influence of chemical factors of the environment", state registration number $0115 \mathrm{U} 000240$.

Introduction. The excessive aggression is an actual problem of modern society but the mechanisms of aggressiveness development have not been sufficiently investigated. Women aggression is considered to differ from men one and results obtained on males can not be extrapolated on females [1]. Sex hormones have a crucial role in the generation of sexually dimorphic aggression circuits during development and their maintenance during adulthood [2]. The conversion of testosterone into estrogen in the brain is a key mechanism of many physiological and behavioral processes regulation throughout an animal's life by testosterone [3]. Female fetus is protected from maternal and its own estrogens by alpha-fetoprotein, which binds to estrogens and prevents them from entering to neurons to masculinize them [4]. Hypothalamic pituitary adrenal (HPA) axis and sympathoadrenal system (SAS) are major neuroendocrine systems that respond to stress. Stress hormones are involved into behavioral reactions of organism [5-6]. Gonadal, HPA axes and SAS are tightly interrelated and every of them can influence another ones [7, 8].

The purpose of the work was to estimate correlation differences between sex and stress hormones in men and women.

Material and Methods. Forty healthy young people aged 18 to 22 years with a body mass index of 19-24 (21 women and 19 men), students of Kharkiv National Medical University, were enrolled in the study. All procedures and manipulations were carried out in accordance with the ethical standards of the Committee of Ethics and Bioethics of Kharkiv National 
Medical University and the revised Declaration of Helsinki (2000). All participants signed a written informed consent. All females had the regulatory 28-32-daylong menstrual cycle. They had no surgery and traumas in anamnesis. They have not been taking contraceptives and medicines that may affect their hormonal profile by any way for last 3 months.

In females blood samples were collected 3 times: in follicular, ovulation and luteal phases of menstrual cycle at the same time of day $(8.00-9.00$ a.m.). In males blood samples were collected once, at $8.00-$ 9.00 a.m. Blood serum was prepared and used for hormones level determination. Hormone levels in blood serum were determined by Testosterone, Estradiol, Cortisol ELISA kits (Italy), Epinephrine / Norepinephrine (EPI) ELISA kit (China).

Statistical analysis was performed using nonparametric statistical methods with the help of the Statistica 6.0 software (StatSoft, USA). Mann-Whitney test was used to compare respective parameters in males and females. Wilcoxon test was used to compare parameters in various phases of the cycle. Correlation analysis according to Spearman was used to reveal the relationship between different variables of the same group.

Results and Discussion. Testosterone is considered a male sex hormone, and estradiol is a female sex hormone, but both are present in both men and women, but in different proportions. According to our results, the testosterone/estradiol ratio in men was 144.40 [106.30; 161.19], and in women it ranged from 2.11 [1.58; 3.14] into the follicular phase up to 2.73 [2.00; 4.2] into the luteal phase and was not statistically different depending on the menstrual cycle phase.

In all phases of the menstrual cycle, the cortisol level in women was lower than in men, but in the luteal phase these differences were not statistically significant (in the follicular phase $p=0.044204$; during ovulation $p=0.035989)$ (Fig. 1).

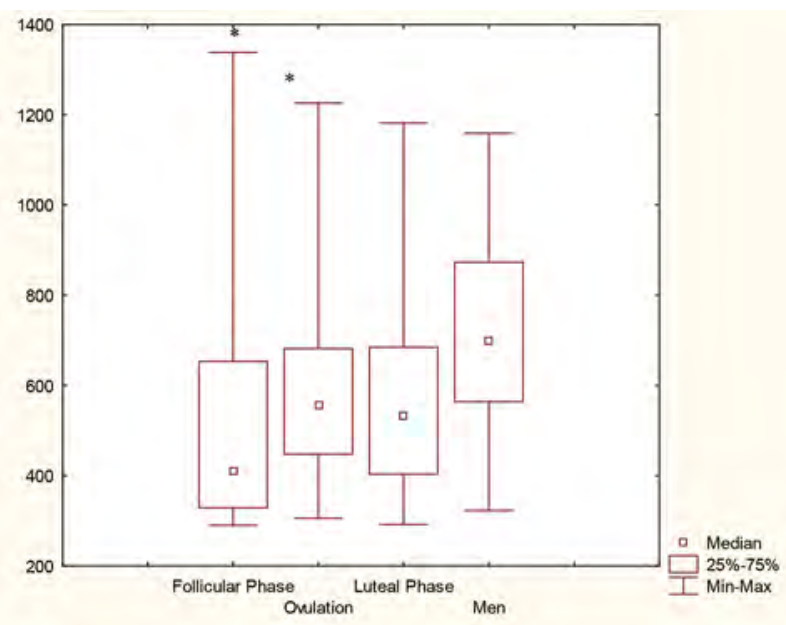

Fig. 1. Cortisol level (nmol/L) in blood serum of men and women (Me [25\%; 75\%], min and max; * $-p<0.05$ versus men)
Our results are consistent with the literature data on the higher content of both the basal total and free cortisol in the blood serum of men as compared to women [9].

In all phases of the menstrual cycle, the blood serum norepinephrine content in women was lower than in men, but in the follicular phase these differences were not statistically significant (during ovulation $p=0.000984$; in the luteal phase $p=0.001345$ ) (Fig. 2).

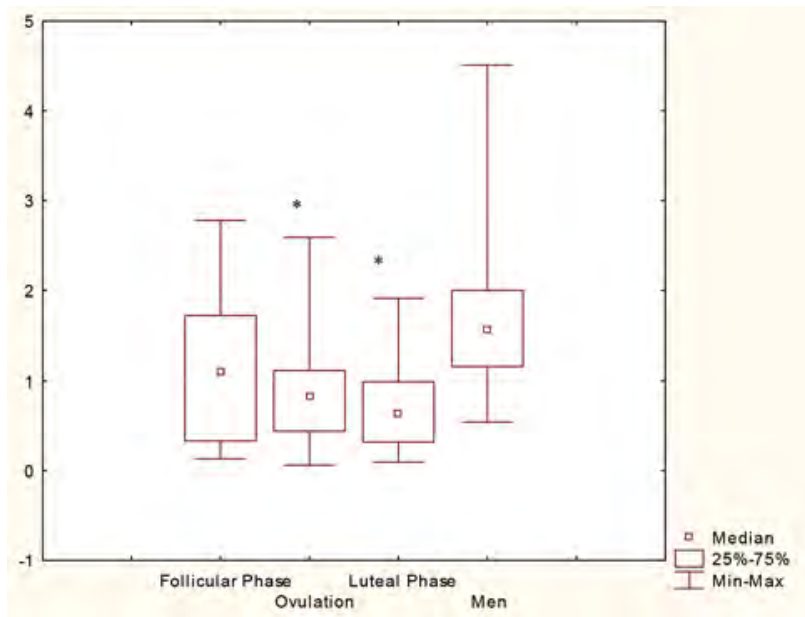

Fig. 2. Norepinephrine level (nmol/L) in blood serum of men and women (Me [25\%; 75\%], min and max; * $-p<0.05$ versus men)

The level of epinephrine in women during ovulation and luteal phase did not differ from the level of epinephrine in men, but in the follicular phase it was significantly lower $(p=0.028733)$ (Fig. 3$)$.

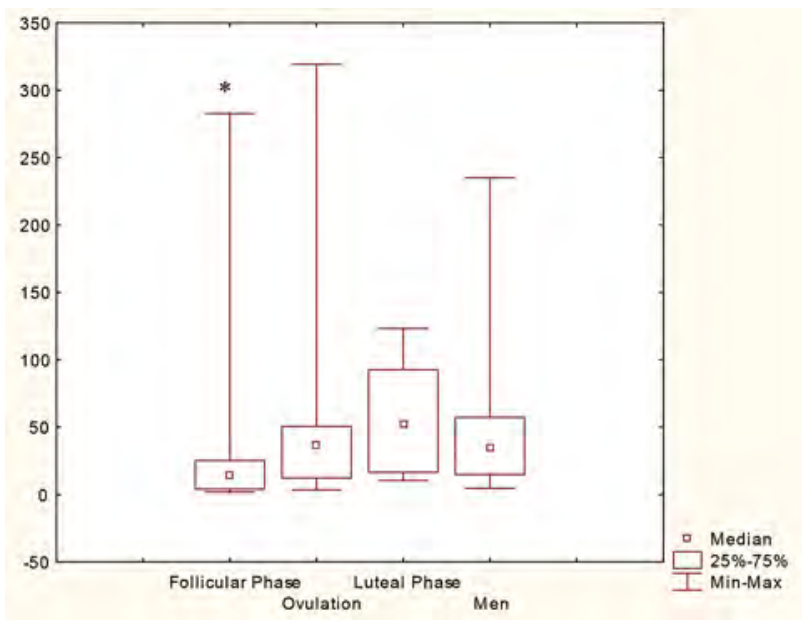

Fig. 3. Epinephrine level ( $\mathrm{nmol} / \mathrm{L})$ in blood serum of men and women (Me [25\%; 75\%], min and max; * $-p<0.05$ versus men)

In the literature, there is evidence that not absolute quantity of hormones, but their ratio is important for some their effects. For example, the ratio of testosterone to cortisol is important for the formation of dominance and the development of aggression [10]. 
In individuals with low cortisol, testosterone correlates positively with dominance, and in individuals with high cortisol, the association between testosterone and dominance is blocked and even acquires the opposite direction [10]. In this regard, we calculated correlation relationships not only between hormones but also their ratios.

Calculations of correlations between individual hormones revealed a significant difference between them in men and women. Thus, positive correlations between testosterone and estradiol $(r=+0.50$, $p=0.028768)$ and between cortisol and epinephrine $(r=+0.86, p=0.000003)$; a strong negative correlation between epinephrine and testosterone/norepinephrine ratio $(r=-0.79, p=0.000048)$ were found in men.

In women in the follicular phase, strong correlations were found between testosterone and cortisol $(r=+0.60, p=0.013626)$, testosterone/estradiol ratio and cortisol $(r=+0.76, p=0.000907)$, estradiol and cortisol/testosterone ratio $(r=-0.66, p=0.007331)$. Women in the luteal phase were found to have the same correlation relationships as in the follicular phase, except for the association between estradiol and the cortisol/testosterone ratio, namely: between testosterone and cortisol $(r=+0.67, p=0.016831)$, the testosterone/estradiol ratio and cortisol $(r=+0.78$, $p=0.002705$ ). These correlations are consistent with the results of Sharma A.N. et al, according to which it is estradiol, not testosterone, that enhances cortisol-mediated feedback on pulsatory ACTH secretion [11].

During ovulation in women, only the correlation between the testosterone/ norepinephrine and cortisol/norepinephrine ratios was observed $(r=+0.75$, $p=0.000820$ ). It should be noted that the correlation between the above ratios was observed in all groups: in women in all phases of the menstrual cycle (follicular phase $-r=+0.92, p=0.000003$; luteal phase $-r=+0.85$, $p=0.000807)$, in men $(r=+0.63, p=0.003983)$.

Gonadal hormones have both organizational and activational effects on central nervous system. Organizational effects of testosterone during embryonic development are mainly realized through its conversion into beta-estradiol and predetermine neural pathways (brain masculinization). Organizational effects during puberty play the important role in brain maturation and connections between brain areas. Progesterone and testosterone have diverging effects on the communication between amygdala and prefrontal cortex (van Wingen et al, 2010) [12]. Prefrontal cortex plays a crucial role in neuroendocrine stress responses and emotion regulation and it is characterized by high expression of genes associated with gonadal and HPA axes [7]. In men, cortisol is positively associated with the functional connectivity of amygdala with striatum and frontal regions; in women, it is negative. Stress increases the connectivity between amygdala and striatum (Vogel et al, 2015) and frontal cortex (Veer et al, 2011) in males only [13]. The sex diverging development of brain areas involved into behavioral and stress reactions can explain the differences between sex in the levels and correlations of the above-mentioned hormones.

In animals, testosterone reduces cortisol reactivity to stress, but in men the effect of testosterone depends on stressor type and personality traits of individual. Exogenous testosterone increases cortisol concentration in response to a social-evaluative stressor, especially in men with high dominance trait [14]. The lack of correlations between cortisol and testosterone in men may be due to the heterogeneity of the group relative to dominance. Strong positive correlation between cortisol and epinephrine may be explained by glucocorticoids stimulation of phenylethanolamine-N-methyltransferase activity in a subpopulation of epinephrine-containing chromaffin cells [15].

\section{Conclusion}

1. Women had statistically significant and lower serum cortisol and norepinephrine levels than men.

2. In women, strong correlations were found between cortisol and sex hormones.

3. In men, a strong positive correlation between cortisol and epinephrine was revealed maybe due to stimulation of phenylethanolamine- $\mathrm{N}$ methyltransferase activity by glucocorticoids.

4. Both in men and in women (in all phases of the menstrual cycle), high positive correlation between the testosterone/norepinephrine and cortisol/norepinephrine ratios was observed.

The prospects for further research will concern the study of differences between blood serum levels of thyroid hormones in men and women.

\section{References}

1. Kalemi G, Michopoulos I, Efstathiou V, Konstantopoulou F, Tsaklakidou D, Gournellis R, et al. Narcissism but Not Criminality Is Associated With Aggression in Women: A Study Among Female Prisoners and Women Without a Criminal Record. Front Psychiatry. 2019; 10: 21. doi: 10.3389/fpsyt.2019.00021

2. Hashikawa K, Hashikawa Y, Lischinsky J, Lin D. The Neural Mechanisms of Sexually Dimorphic Aggressive Behaviors. Trends Genet. 2018; 34(10): 755-76. PMID: 30173869. doi: 10.1016/j.tig.2018.07.001

3. Roselli CE, Liu M, Hurn PD. Brain aromatization. Classical roles and new perspectives. Semin Reprod Med. 2009; 27(3): 207-27. doi: 10.1055/s-0029-1216274 
4. McHenry J, Carrier N, Hull E, and Kabbaj M. Sex Differences in Anxiety and Depression: Role of Testosterone. Front Neuroendocrinol. 2014; 35(1): 42-57. doi: 10.1016/j.yfrne.2013.09.001

5. Senn V, Wolff SB, Herry C, Grenier F, Ehrlich I, Gründemann J, et al. Long-range connectivity defines behavioral specificity of amygdala neurons. Neuron. 2014; 81(2): 428-37. PMID: 24462103. doi: 10.1016/j. neuron.2013.11.006

6. Shabanov PD, Lebedev AA. Neurochemical mechanisms of the nucleus accumbens realizing the reinforcing effects of self-stimulation on the lateral hypothalamus. Med Acad Journal. 2012; 12(2): 68-76. doi: 10.17816/ MAJ12268-76

7. Birgit L, Bhaskar R, Dwivedi Y. Role of HPA and the HPG Axis Interaction in Testosterone-Mediated Learned Helpless Behavior. Mol Neurobiol. 2019; 56(1): 394-405. PMID: 29704202. doi: 10.1007/s12035-018-1085-x

8. Peng R, Dai W, Li Y. Neuroprotective effect of a physiological ratio of testosterone and estradiol on corticosteroneinduced apoptosis in PC12 cells via Traf6/TAK1 pathway. Toxicol In Vitro. 2018; 50: 257-263. PMID: 29625166. doi: 10.1016/j.tiv.2018.03.018

9. Sofer Y, Osher E, Limor R, Shefer G, Marcus Y, Shapira I, et al. Gender determines serum free cortisol: higher levels in men. Endocr Pract. 2016; 22(12): 1415-1421. PMID: 27540879. doi: 10.4158/EP161370.OR

10. Mehta $\mathrm{PH}$, Josephs RA. Testosterone and cortisol jointly regulate dominance: evidence for a dual-hormone hypothesis. Horm Behav. 2010; 58.(5): 898-906.

11. Sharma AN, Aoun P, Wigham JR, Weist SM, Veldhuis JD. Estradiol, but not testosterone, heightens cortisolmediated negative feedback on pulsatile ACTH secretion and ACTH approximate entropy in unstressed older men and women. Am J Physiol Regul Integr Comp Physiol. 2014; 306(9): R627-R635. PMCID: PMC4010660 PMID: 24573184. doi: 10.1152/ajpregu.00551.2013

12. Durdiakova J, Ostatnikova D, Celec P. Testosterone and its metabolites - modulators of brain functions. Acta Neurobiol Exp. 2011; 71: 434-454.

13. Kogler L, Mueller VI, Seidel E, Boubela R, Kalcher K, Moser E, et al. Sex differences in the functional connectivity of the amygdalae in association with cortisol. Neuroimage. 2016; 134: 410-423. doi: 10.1016/j. neuroimage.2016.03.064

14. Knight EL,Christian CB, Morales PJ, Harbaugh WT, Mayr U, Mehta PL. Exogenous testosterone enhances cortisol and affective responses to social-evaluative stress in dominant men. Psychoneuroendocrinology . 2017; 85: 151-157. PMID: 28865351. PMCID: PMC5798202. doi: 10.1016/j.psyneuen.2017.08.014

15. de Diego AM, Gandía L, García AG. A physiological view of the central and peripheral mechanisms that regulate the release of catecholamines at the adrenal medulla. Acta Physiol (Oxf). 2008; 192(2): 287-301. PMID 18005392

УДК 577.175.5/.6-055.1/.2

КОРЕЛЯЦІЙНІ ВІДМІННОСТІ МІЖ СТАТЕВИМИ ГОРМОНАМИ

ТА ГОРМОНАМИ СТРЕСУ У ЧОЛОВІКІВ ТА ЖІНОК

Попова Л. Д., Васильєва І. М., Наконечна О. А.

Резюме. Надмірна агресивність $€$ актуальною проблемою сучасного суспільства, але механізми розвитку агресивності недостатньо досліджені. Вважається, що агресивність жінок відрізняється від чоловічої, і результати, отримані на чоловіках, не можуть бути екстрапольовані на жінок.

Метою роботи була оцінка кореляційних відмінностей між статевими гормонами та гормонами стресу у чоловіків та жінок.

До дослідження було залучено сорок здорових молодих людей віком від 18 до 22 років з індексом маси тіла 19-24 (21 жінка та 19 чоловіків). Рівні гормонів (тестостерону, естрадіолу, кортизолу, адреналіну, норадреналіну) в сироватці крові визначали імуноферментним методом. У всіх фазах менструального циклу рівень кортизолу у жінок був нижчим, ніж у чоловіків, але в лютеїновій фразі ці відмінності не були статистично значущими. У всіх фазах менструального циклу вміст норадреналіну в сироватці крові у жінок був нижчим порівняно з чоловіками, проте у фолікулярній фразі ці відмінності не були достовірними.

Рівень адреналіну у жінок під час овуляції та лютеїнової фази не відрізнявся від рівня адреналіну у чоловіків, але у фолікулярній фазі він був значно нижчим. Розрахунки кореляцій між окремими гормонами виявили суттєву різницю між ними у чоловіків і жінок. У жінок були виявлені сильні кореляційні зв'язки між кортизолом і статевими гормонами (позитивний кореляційний зв'язок між тестостероном і кортизолом; негативний кореляційний зв'язок між естрадіолом і співвідношенням кортизол/тестостерон). У чоловіків виявлено сильну позитивну кореляцію між кортизолом та адреналіном.

Як у чоловіків, так і у жінок (у всі фрази менструального циклу) спостерігалася висока позитивна кореляція між співвідношеннями тестостерон/ норадреналін та кортизол/норадреналін.

Ключові слова: тестостерон, естрадіол, кортизол, адреналін, норадреналін, чоловіки, жінки. 
УДК 577.175.5/.6-055.1/.2

КОРРЕЛЯЦИОННЫЕ РАЗЛИЧИЯ МЕЖДУ ПОЛОВІМИ ГОРМОНАМИ

И ГОРМОНАМИМ СТРЕССА У МУЖЧИН И ЖЕНЩИН

Попова Л. Д., Васильева И. М., Наконечная О. А.

Резюме. Чрезмерная агрессивность является актуальной проблемой современного общества, но механизмы развития агрессивности недостаточно исследованы. Считается, что агрессивность женщин отличается от мужской, и результаты, полученные на мужчинах, не могут быть экстраполированы на женщин.

Целью работы была оценка корреляционных различий между половыми гормонами и гормонами стресса у мужчин и женщин. В исследовании приняли участие 40 здоровых молодых людей в возрасте от 18 до 22 лет с индексом массы тела 19-24 (21 женщина и 19 мужчин). Уровни гормонов (тестостерона, эстрадиола, кортизола, адреналина, норадреналина) в сыворотке крови определяли иммуноферментным методом.

Во всех фразах менструального цикла уровень кортизола у женщин был ниже, чем у мужчин, но в лютеиновой фазе эти различия не были статистически значимыми. Во всех фазах менструального цикла содержание норадреналина в сыворотке крови у женщин было ниже по сравнению с мужчинами, но в фолликулярной фазе эти различия не были достоверными.

Уровень адреналина у женщин во время овуляции и лютеиновой фазы не отличался от уровня адреналина у мужчин, но в фолликулярной фазе он был значительно ниже. Расчеты корреляций между отдельными гормонами выявили существенное различие между ними у мужчин и женщин. У женщин были обнаружены сильные корреляционные связи между кортизолом и половыми гормонами (положительная корреляционная связь между тестостероном и кортизолом; отрицательная корреляционная связь между эстрадиолом и соотношением кортизол/тестостерон). У мужчин обнаружена сильная положительная корреляция между кортизолом и адреналином.

Как у мужчин, так и у женщин (во все фазы менструального цикла) наблюдалась высокая положительная корреляция между соотношениями тестостерон/норадреналин и кортизол/норадреналин.

Ключевые слова: тестостерон, эстрадиол, кортизол, адреналин, норадреналин, мужчины, женщины.

The authors of this study confirm that the research and publication of the results were not associated with any conflicts regarding commercial or financial relations, relations with organizations and/or individuals who may have been related to the study, and interrelations of coauthors of the article. 